\title{
Population biology of Trapezia spp. and other coral-associated decapods
}

\author{
Nicholas J. Gotelli, Sandra L. Gilchrist* and Lawrence G. Abele \\ Department of Biological Science, Florida State University, Tallahassee, Florida 32306, USA
}

\begin{abstract}
We describe the population structure of 3 coexisting species of Trapezia and 4 other common decapod species associated with the reef coral Pocillopora in the Eastern Pacific Ocean. Most species carry eggs throughout the year, and egg number is highly correlated with body size. Trapezia postlarvae (= postmegalopa) recruit in April and June only and reach adult size by the following January. Sex ratios vary among species and may be affected by the frequency of movement among coral heads. Decapod abundance is often higher on the shallow reef flat, where Pocillopora cover is more continuous and predatory fishes are less common. In contrast to many 'community' studies, area (coral head size) is not an important predictor variable, except for a modest effect on abundance. Instead, season and reef location emerge as the most important correlates with population structure of decapod species associated with Pocillopora.
\end{abstract}

\section{INTRODUCTION}

A rich fauna of decapod crustaceans inhabits the living branches of Pocillopora spp., a Pacific reef coral (Abele, 1976b; Abele and Patton, 1976; Castro, 1976). The community has been well studied, particularly in the Eastern Pacific Ocean (Abele, 1976a, 1976b; Abele and Patton, 1976; Castro, 1976, 1978, 1982; Glynn 1976, 1980, 1983a; Gotelli and Abele, 1983). Abele (1976a, 1979) compared species numbers and speciesarea curves for coral heads from the Bay of Panama and the Gulf of Chiriqui. Glynn (1976) reported on the distribution of 2 common species (Trapezia ferruginea Latreille, Alpheus lottini Guerin) on 119 heads collected from Uva Island, a patch reef in the Gulf of Chiriqui. Gotelli and Abele (1983) examined patterns of association and co-occurrence of species in this same collection. Community patterns have also been reported for collections from Australia (Patton, 1974; Austin et al., 1980; Black and Prince, 1983), Hawaii (Preston, 1973; Coles, 1980) and the Red Sea (associates of Stylophora; Edwards and Emberton, 1980). Abele (1984) summarizes community structure and colonization experiments in Australia and the Central Pacific.

- Present address: New College, Division of Natural Sciences, 5700 N. Tamiami Trail, Sarasota, Florida 33580, USA
In spite of these community studies, we still know little of the population biology of many coral-associated decapods (Castro, 1976). The purpose of this work is to document patterns in the population structure, body size, egg number, and fecundity of seven common species associated with Pocillopora in the Eastern Pacific. We return to Glynn's (1976) Uva Island corals, which were collected carefully on 4 sampling dates (Jan, Apr, Jun, Aug) and 2 reef locations (reef flat and reef flank; see Glynn [1976] for terminology). These data allow us to document spatial and temporal variation in several population measures.

We have concentrated on the patterns manifest by 3 closely related, syntopic xanthid crabs: Trapezia ferruginea Latreille, Trapezia corallina Gerstaeker, and Trapezia formosa (Smith). A fourth Eastern Pacific species, Trapezia digitalis, was collected only once at Uva and is not considered here. Trapezia spp. are brightly colored obligate associates of live pocilloporid corals; they feed on coral mucus (Knudsen, 1967; Patton, 1974; but see Crane, 1937). Individuals migrate between coral heads at night and establish malefemale pairs (Castro, 1978), which may exclude other individuals from a coral head (Preston, 1973). Trapezia actively defend their host coral from attacks by the crown-of-thorns seastar, Acanthaster (Weber and Woodhead, 1970), as well as increasing coral vitality by promoting cleansing activities and branch elonga- 
tion (Glynn, 1983a). Although Eastern Pacific Trapezia are very similar in morphology and appearance, our comparative analysis reveals their population biology is quite distinct.

In addition to the common species of Trapezia, we present some brief notes on the biology and population structure of 4 other Pocillopora associates: a snapping shrimp (Alpheus lottini Guerin), 2 palaemonid shrimp (Fennera chacei Holthuis and Harpiliopsis depressa [Stimpson]), and a spider crab (Teleophrys cristulipes Stimpson). Taken together, these 7 species are typical co-occurring residents of a single coral head.

In a previous analysis (Gotelli and Abele, 1983), we detected subtle correlations of abundance among Trapezia: a positive correlation between Trapezia ferruginea and Trapezia corallina and a negative correlation between Trapezia corallina and Trapezia formosa. But our main finding was that indices of correlation and association among species were distributed randomly. In other words, the abundances of these 7 species appear to fluctuate independently of one another, at least in a statistical sense. This finding provides a rationale for our analysis, in which we consider the population structure of coral-associated decapods on a species-by-species basis.

\section{MATERIALS AND METHODS}

P. W. Glynn collected coral heads and their associated fauna during January $(\mathrm{n}=56$ ), April ( $\mathrm{n}=29$ ), June $(n=24)$, and August $(n=10) 1973$ from a patch reef at Uva Island, Gulf of Chiriqui, Panama. These sampling dates include the dry season (Jan, Apr) and the wet season (Jun, Aug). A total of 119 live coral heads were selected at random from the shallow reef flat $(n=52)$ and the deeper reef flank $(n=57)$. Intact coral heads were bagged and then broken off at the base. Bags were sealed and taken to the surface, where the length, width, and depth of each coral head was measured and epibionts were removed. These measurements were used to calculate coral head volume, which is correlated with surface area (Barry, 1965). Animals associated with the dead coral base were not included. All coral heads sampled were in the genus Pocillopora, including $P$. damicornis, $P$. robusta, $P$. capitata, and $P$. lacera. Most coral associates do not appear to differentiate among congeneric coral species (Garth, 1964; Patton, 1966; Castro, 1976).

All specimens of Trapezia from a single coral head were kept together. Unfortunately, the January samples were combined before it was realized that the Trapezia belonged to 3 species, not just 1 . Consequently, some of our statistical analyses for Trapezia are incomplete and do not include the January data. A series of measurements were taken on each individual, although carapace length (CL) was used as a primary measure of body size because it has no differential growth associated with the onset of sexual maturity (Finney and Abele, 1982).

A total of 1,388 individuals of Trapezia spp. were examined and divided into 3 age classes: postlarvae (= postmegalopa individuals that could not be sexed; less than $2.5 \mathrm{~mm} \mathrm{CL}$ ), juvenile males and females (= individuals less than $6.5 \mathrm{~mm} \mathrm{CL}$ for $T$. ferruginea and $T$. formosa; $4.5 \mathrm{~mm}$ CL for $T$. corallina), and adult males and fermales $(6.5 \mathrm{~mm}$ CL or larger; $4.5 \mathrm{~mm} \mathrm{CL}$ for $T$. corallina). We used $6.5 \mathrm{~mm} \mathrm{CL}(4.5 \mathrm{~mm} \mathrm{CL}$ for $T$. corallina) as the size dividing mature from immature individuals of $T$. ferruginea and $T$. formosa based on morphometric studies of this species complex (Finney and Abele, 1982). However, any ovigerous female, regardless of size, was considered to be sexually mature. Ovigerous females of $T$. ferruginea ranged in size from 5.0 to $11.0 \mathrm{~mm} \mathrm{CL}$, those of $T$. formosa from 6.3 to $13.0 \mathrm{~mm} \mathrm{CL}$, and those of $T$. corralina from 3.5 to $10.1 \mathrm{~mm}$ CL.

We determined the number of eggs carried by females of different body sizes by first wet-weighing preserved egg samples of 250 to 2,500 eggs in increments of 250 eggs. The relation between egg weight and egg number was then determined by linear regression. The correlation coefficient of this relation is greater than .99. From the January samples, a group of 70 females (30 Trapezia ferruginea, $20 \mathrm{~T}$. corallina, 20 $T$. formosa) were measured, and the entire egg mass of each individual was removed and wet-weighed. We estimated egg number from the regression on egg weight and regressed the resulting egg numbers on body dimensions.

To examine seasonal and locational variation in abundance, an analysis of covariance was used. Most species abundances are positively correlated with coral-head size, and the ANCOVA removes the confounding effects of area. All analyses were performed on $\log _{10}$-transformed data. (To incorporate O's, densities were increased by one before logarithms were taken.) Except for Harpiliopsis depressa, the loglog model provided the best linear fit.

Other population data were analysed as a multi-way contingency table. Each individual collected was classified by season (Jan, Apr, Jun, or Aug), location (reef flat or reef flank), and a dichotomous population variable (e.g. adult or juvenile). Significant interactions between population variables and season or location suggest that population structure varies temporally or spatially.

The ANCOVA's were computed using the regression technique (Huitema, 1980) on SPSS version 9.0, and the contingency tables were analysed using BMDP3F, 
the Multi-way Contingency Tables program. All computations were performed on the Cyber 760, at the Florida State University Computing Center.

\section{RESULTS}

\section{Trapezia spp. complex}

Egg number, recruitment, and body size

Egg diameters of the 3 species were similar $(0.3 \pm$ $0.5 \mathrm{~mm}$ ). Individuals of Trapezia ferruginea carried from 6 to 7,606 eggs, $T$. corallina from 9 to 2,092 eggs, and $T$. formosa from 568 to 4,145 eggs. It is possible that the individuals carrying few eggs had just started to place them on the pleopods and that more would have been deposited later. In addition, females may have released larvae and not retained the egg capsules, so we may have under estimated egg number in some cases. There is a significant positive correlation between log egg number and log body size for $T$. ferruginea and $T$. corallina but not for $T$. formosa (Fig. 1).

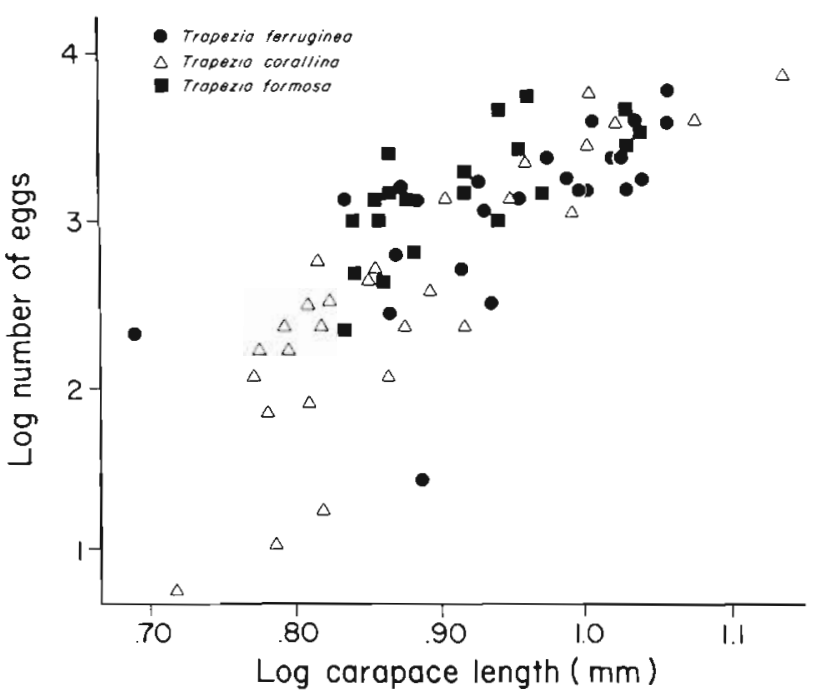

Fig. 1. Egg number as a function of carapace length for 3 species of Trapezia. All regression equations are on log-log scale. Trapezia ferruginea: $y=-3.47+6.26 x\left(\mathrm{r}^{2}==.69\right.$; $\mathrm{p}<.01) ;$ Trapezia corallina: $\mathrm{y}=-5.36+8.40 \mathrm{x}\left(\mathrm{r}^{2}=.66\right.$; $\mathrm{p}<.01) ;$ Trapezia formosa: $y=1.87+1.29 \mathrm{x}\left(\mathrm{r}^{2}=.09\right.$; $p>.051$

Thus, females that differ slightly in body size differ dramatically in egg number. For example, a $9 \mathrm{~mm}$ female of $T$. ferruginea would carry 399 eggs, whereas a $10 \mathrm{~mm}$ female would carry almost twice that number, 655 .
The proportion of females carrying eggs varied significantly among species (Fig. 2 A). The fecundities of Trapezia formosa $(90 \%)$ and T. ferruginea $(81 \%)$ were constant throughout the year and were similar for reef flat and flank samples. For $T$. corallina, however, the

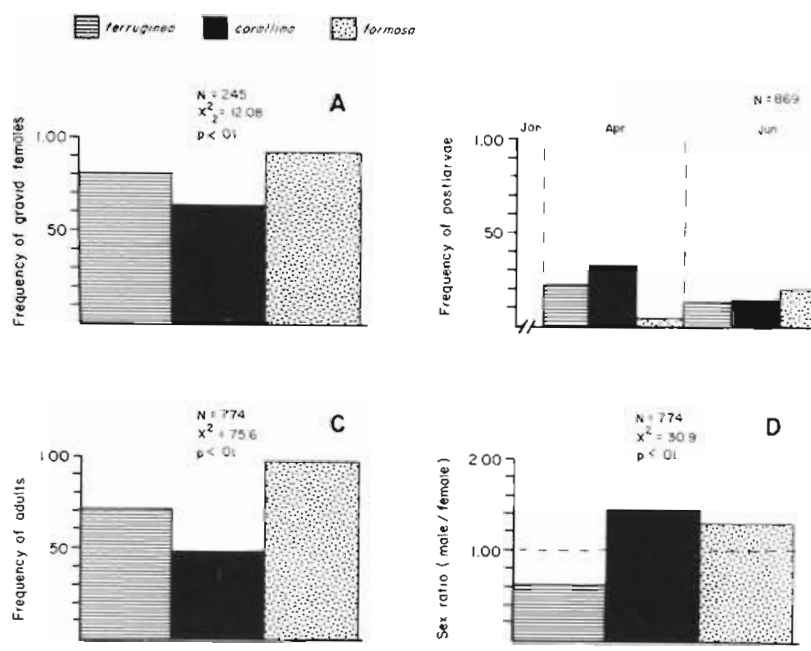

Fig. 2 (A). Frequency of occurrence of adult Trapezia females carrying eggs. (B) Frequency of occurrence of Trapezia postlarvae at 4 sampling dates. (C) Frequency of occurrence of adult Trapezia. (D) Total sex ratios (male/female) of Trapezia

occurrence of gravid females varied both seasonally and by reef location. Seasonally, fecundity was highest in January (96\%), lowest in June (20\%). Of the females collected on the reef flat, $45 \%$ were carrying eggs, compared to $80 \%$ for reef flank females.

For all 3 species of Trapezia, at least some females carried eggs at all sampling dates. Because eggs were carried throughout the year, one might expect continuous recruitment of postlarvae onto coral heads. But this was not the case. No postlarvae were collected during January or August. Recruitment of postlarvae varied among species, but was heaviest in April (except for T. formosa; Fig. 2 B). Flank and flat frequencies appear similar. Even within a season, postlarvae recruitment varied tremendously on a head-to-head basis.

The proportion of adults in the population also varies among species, from $48 \%$ for Trapezia corallina to $98 \%$ for Trapezia formosa (Fig. 2 C). These percentages do not vary significantly by season or reef location. The size-frequency distributions for each species over the 4 sampling periods are shown in Fig. $3 \mathrm{~A}-\mathrm{C}$. In all cases, the largest (mean sizes) crabs were collected during January and the smallest (except for female $T$. ferruginea) during August. Apparently, postlarvae of $T$. corallina that settle during April and June reach juvenile size by August and adult size by January. Our evidence is that the occurrence of juveniles increases 

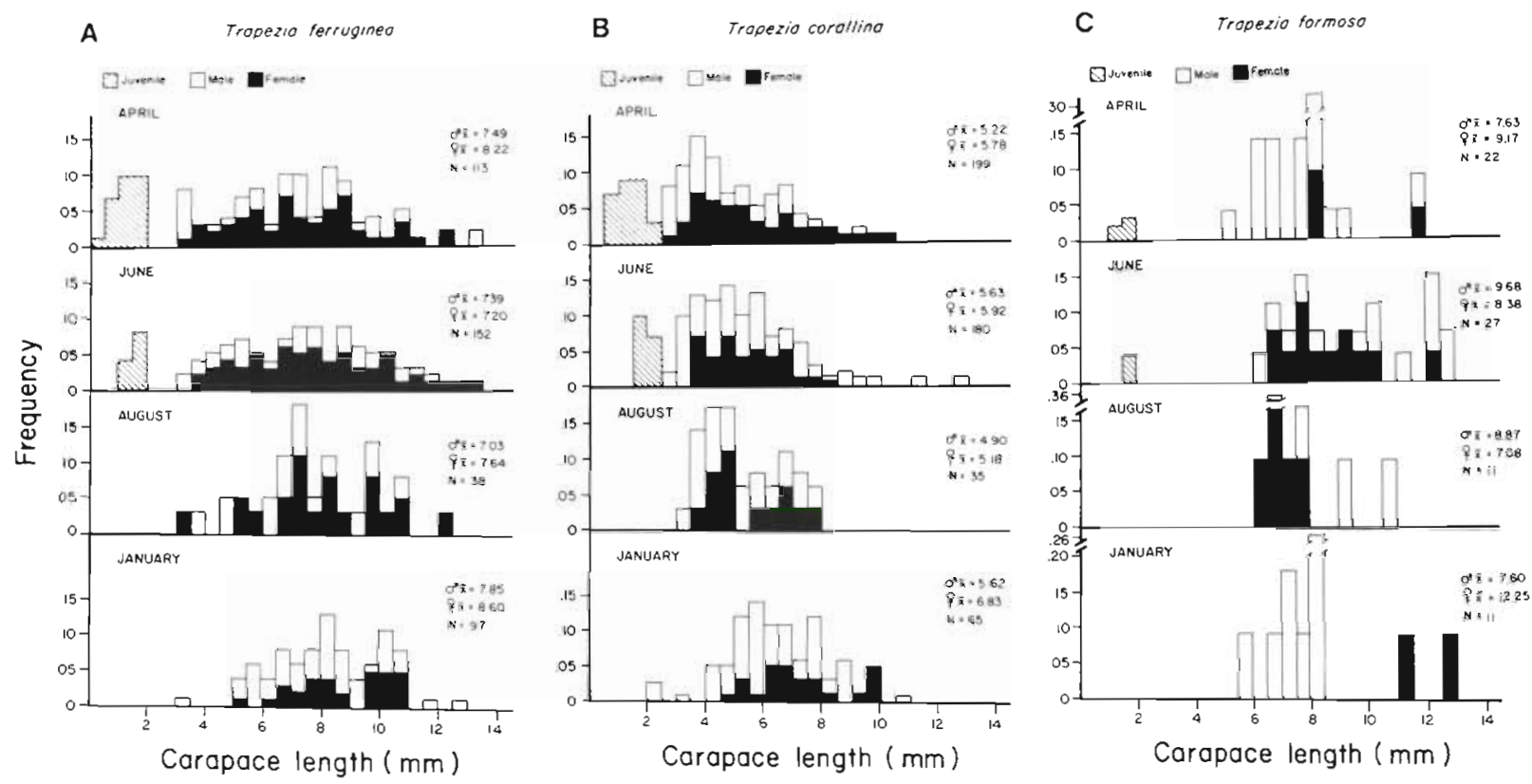

Fig. 3. Size-frequency distributions of Trapezia on 4 sampling dates in 1973. Average sizes are given by sex for each sample. Dark bars: females; clear bars: males; open bars: postlarvae. January sample is drawn last to illustrate seasonal patterns in body size

during August (50\%), but decreases in January (36\%), as individuals presumably grow to adult size. These seasonal changes in the percentage of juveniles are not statistically significant, but they are consistent with the hypothesis that $T$. corallina postlarvae that settle in April or June reach juvenile size in August and adult size in January. The mean sizes of $T$. ferruginea follow a similar pattern, but the percentage of juveniles is lowest in August (26\%) and highest in January (38\%). Only 1 juvenile of $T$. formosa was collected, so we cannot make any statements about the population structure of this species.

Density and distribution

Trapezia ferruginea and $T$. corallina were present on neariy every coral head, whereas $T$. formosa was present on only $55 \%$ of the coral heads. Frequency of occurrence is not affected by coral head size or season, but is affected by reef location. Trapezia formosa was present on $71 \%$ of the reef-flat heads, compared to only $37 \%$ of the reef-flank heads.

The abundance of Trapezia formosa is uncorrelated with coral head size (Table 1), but is significantly higher on the reef flat ( $\bar{x}=1.08$ individuals/head) than

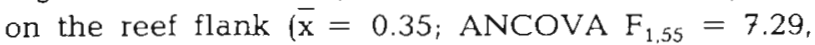
$\mathrm{p}<0.05$ ). However, this result is obtained because the frequency of occurrence is greater on the reef flat. If the analysis is restricted to those samples in which $T$. for-
Table 1. Regression models of $\log _{10}$ (abundance +1 ) vs. $\log _{10}$ (area) for 7 common coral associates

\begin{tabular}{|lrrrrr|}
\hline \multicolumn{1}{|c}{ Species } & $N$ & $\begin{array}{c}\text { Inter- Slope } \\
\text { cept }\end{array}$ & $\mathrm{r}^{2} \begin{array}{c}\text { Signifi- } \\
\text { cance of } \\
\text { regres- } \\
\text { sion }\end{array}$ \\
\cline { 1 - 5 } Trapezia ferruginea & 58 & -.64 & .41 & .31 & $\mathrm{p}<.01$ \\
Trapezia corallina & 58 & -.43 & .37 & .20 & $\mathrm{p}<.01$ \\
Trapezia formosa & 58 & .01 & .06 & .00 & $\mathrm{p}=.49$ \\
Alpheus lottini & 119 & -.34 & .21 & .10 & $\mathrm{p}<.01$ \\
Fennera chacei & 119 & -.88 & .44 & .06 & $\mathrm{p}<.01$ \\
Harpiliopsis depressa & 119 & -.34 & .28 & .07 & $\mathrm{p}<.01$ \\
Teleophrys cristulipes & 119 & -1.52 & .64 & .21 & $\mathrm{p}<.01$ \\
\hline
\end{tabular}

mosa is actually present, flank and flat densities are similar.

The abundance of Trapezia ferruginea is well correlated with coral head size (Table 1 ). As with $T$. formosa, the abundance of $T$. ferruginea is higher on the reef flat $\left(\bar{x}=4.99\right.$ indiv. head $\left.^{-1}\right)$ than on the reef flank $\left(\bar{x}=3.52\right.$; ANCOVA $\left.F_{1,55}=11.18, p<0.01\right)$. In this case, however, the result is not caused by differences in the frequency of occurrence at the two sites; $T$. ferruginea was absent from only one coral head in the entire collection. Seasonal differences in abundance are not significant. For T. corallina, abundance is also a function of coral-head size (Table 1), but in this case there were no significant effects of season or reef location on abundance. 


\section{Sex ratios}

Sex ratio, both total and adult, does not vary by season or reef location, although differences among species are clear (Fig. 2 D). Of the Trapezia ferruginea collected $61 \%$ were females, compared to only $40 \%$ of $T$. corallina and $42 \%$ of $T$. formosa. The sex ratio for $T$. formosa does not differ significantly from unity, whereas the ratios for $T$. ferruginea and $T$. corallina are definitely skewed. Thus, the sex ratio of $T$. ferruginea is skewed toward females, that of $T$. corallina toward males, and that of $T$. formosa is unskewed (although this may be an artifact of small sample size). Night samples might reveal other patterns because of crustacean movements.

\section{Notes on other Pocillopora associates}

\section{Alpheus lottini Guerin}

This large (total length approx. 20 to $27 \mathrm{~mm}$ ), conspicuous snapping shrimp is a common associate of pocilloporid corals throughout the Pacific. Adults associate as male-female pairs; usually, only a single pair occupies a coral head. The body sizes of coexisting males and females are positively correlated (Patton, 1974). Starved individuals will feed on coral mucus (Patton, 1974), although Coutiere (1899) found eggs in the stomach of one specimen. Stomach contents of Australian specimens were mostly debris and coral mucus (Patton, 1974). Like the Trapezia species, Alpeus lottini actively defends its coral host from attacks by corallivore Acanthaster (Glynn, 1976, 1980). The shrimp snaps aggressively at Acanthaster and will even pinch the seastar's ambulacral spines.

Alpheus lottini was present on $80 \%$ of the coral heads. Abundance is weakly correlated with coral head size (Table 1). Two coral heads contained 7 juvenile individuals, although most heads supported a single adult male-female pair. A. lottini was absent from only 5 coral heads, all of which were collected from the reef flank. These absences affect the estimates of average abundance per coral head. If all samples are used, reef flat heads have a slightly higher adjusted mean density $\left(\overline{\mathrm{x}}\right.$ flat $=2.51$ indiv. head ${ }^{-1}, \overline{\mathrm{x}}$ flank $=$ 1.87; ANCOVA $F_{1.116}=10.56, p<0.01$ ). If the empty heads are excluded, mean densities do not differ. Seasonal differences in density were not significant. There were no significant effects of coral-head size, location, or season on the adult sex ratio, adult-juvenile ratio, or gravid-non-gravid female ratio. The adult sex ratio was $1.0,87 \%$ of the individuals collected were adults, and $91 \%$ of the females were carrying eggs. Eggs are small (diameter about $0.55 \mathrm{~mm}$ ) and numerous, and egg number is highly correlated with body size (Fig. 4).

\section{Fennera chacei Holthuis}

This small (total length approx. 4 to $6 \mathrm{~mm}$ ) pontiniid shrimp has been collected only from Pocillopora (Abele, 1976a), although one report is from Porites (Holthuis, 1951). Fennera chacei ranges from the Eastern Pacific through the Indo-West Pacific, although it is rare in Australia (Patton, 1966). This shrimp is collected at the base of coral heads, often in large numbers (Abele, 1976a). Feeding habits are unknown.

Fennera chacei was present on $72 \%$ of the heads. Density (indiv. coral head ${ }^{-1}$ ) can be quite high - as many as 49 individuals (all adults) were collected from a single head. However, coral head size explains only $6 \%$ of the variation in abundance (Table 1). Seasonal differences in abundance are highly significant (ANCOVA $\left.F_{3,114}=5.31, p<0.01\right)$. Density is highest in the wet season (Jun $\bar{x}=5.3$ indiv. head ${ }^{-1}$; Aug $\bar{x}=$ 7.5) and lowest in the dry season (Jan $\bar{x}=1.7$; April $\bar{x}=2.5$ ). The difference is probably significant because most empty heads were collected in the dry season. If the analysis is repeated using only samples with Fennera chacei present, seasonal differences in density are not significant. Of the individuals collected $99 \%$ were adults. Only 6 juveniles were obtained (from 5 coral heads), all from the April samples. Of the adult females $93 \%$ were carrying eggs. The eggs are relatively large ( 0.4 to $0.5 \mathrm{~mm}$ ) compared to body size, and egg number is highly correlated with body size (Fig. 4). The adult sex ratio is .91, skewed slightly toward females.

\section{Harpiliopsis depressa (Stimpson)}

This medium-sized (total length 16 to $25 \mathrm{~mm}$ ) species of pontiniid shrimp is widespread throughout the Indo-West Pacific, extending to the Galapagos and Eastern Pacific (Bruce, 1981). Harpiliopsis depressa apparently has a long larval life (Bruce, 1970), and postponed settlement from the pelagic phase may be responsible for its widespread distribution (Bruce, 1970, 1976). Patton (1966) suggests that Australian specimens of $H$. depressa prefer Stylophora and Seriatopora corals, whereas the congeneric $H$. beaupressi prefers Pocillopora. In the Eastern Pacific, however, $H$. depressa is commonly collected from Pocillopora (Abele, 1976a). Feeding habits of $H$. depressa are undescribed. Unlike $H$. beaupressi, $H$. depressa has well-developed exopodites on the maxillipeds and may feed on plankton (Bruce, 1976). Harpiliopsis depressa is very similar to the congeneric $H$. spinigera, 

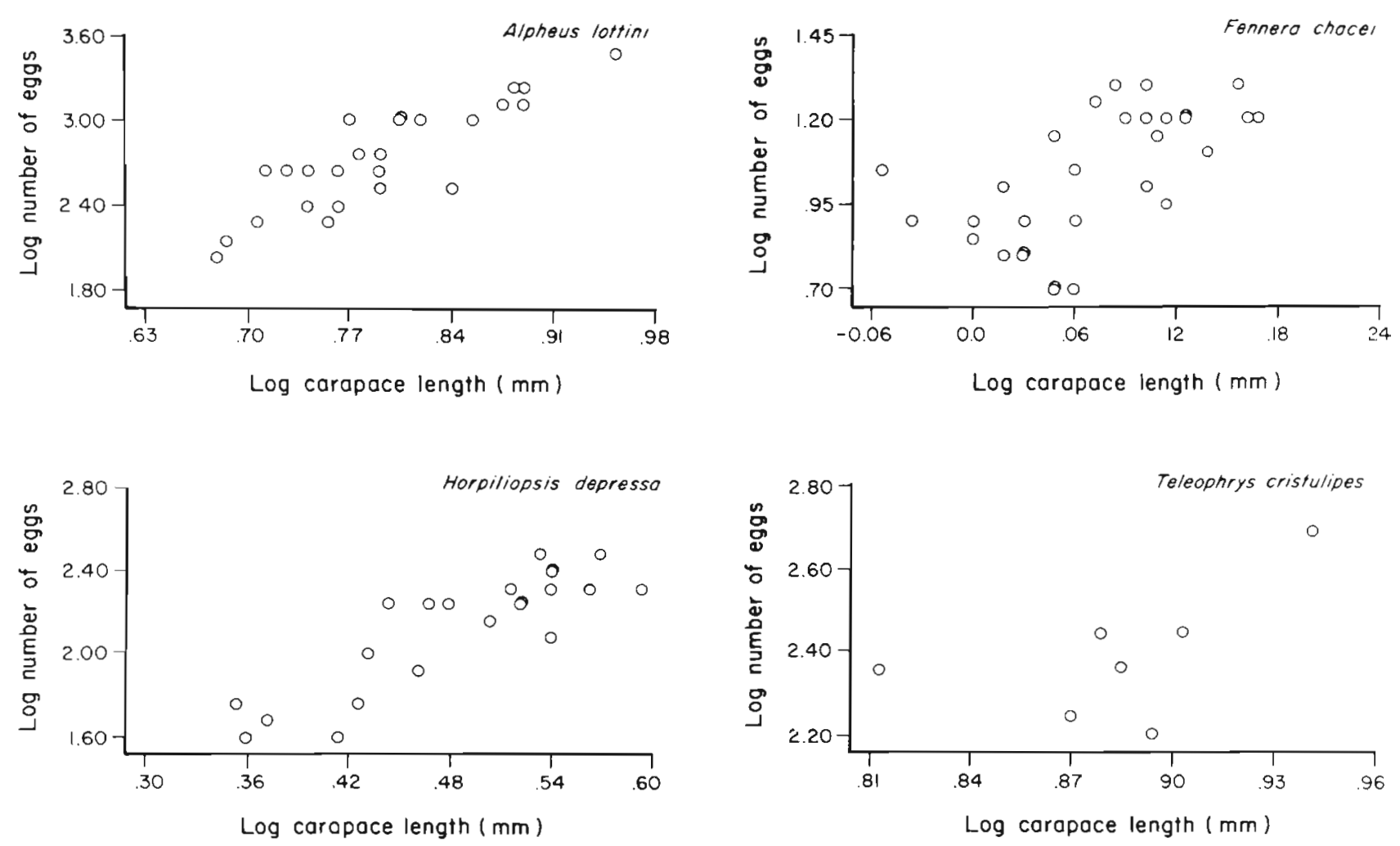

Fig. 4. Egg number as a function of carapace length for 4 decapod species associated with Pocillopora. Alpheus lottini: $y=-.09$ $+4.59 \mathrm{x}\left(\mathrm{r}^{2}=.73 ; \mathrm{p}<.01\right) ;$ Fennera chacei: $\mathrm{y}=.88+2.10 \mathrm{x}\left(\mathrm{r}^{2}=.37 ; \mathrm{p}<.01\right) ;$ Harpiliopsis depressa: $\mathrm{y}=.41+3.53 \mathrm{x}\left(\mathrm{r}^{2}=.77\right.$ $\mathrm{p}<.01) ;$ Teleophrys cristulipes: $\mathrm{y}=.45+2.20 \mathrm{x}\left(\mathrm{r}^{2}=.29 ; \mathrm{p}>.05\right)$

and the 2 species can be reliably separated only on the basis of color (Bruce, 1976). In Australia, all 3 species of Harpiliopsis may be collected from the same coral head (Bruce, 1976). Harpiliopsis beaupressi does not occur in the Eastern Pacific, and $H$. spinigera is uncommon.

Harpiliopsis depressa was present on $92 \%$ of the coral heads. Frequency of occurrence is unaffected by coral head size, season, or reef location. Coral head size explains $7 \%$ of the variation in abundance (Table 1 ). The analysis of covariance revealed significant heterogeneity of regression slopes by season $\left(F_{3,101}=3.04, p<0.05\right)$. Slopes are equivalent if empty coral heads are excluded from the analysis $\left(F_{3,101}=\right.$ $2.56, \mathrm{p}>0.05)$. The linear fit of the $\log$-log regression model is not especially good, unless the empty heads are excluded. Thus, the poor fit of the model, rather than true seasonal variation, probably causes the heterogeneity of the regression slopes. Reef-flat and reef-flank densities do not differ significantly.

Of the individuals collected $86 \%$ were adults. This proportion was constant over all seasons and locations. The adult sex ratio was 0.40 , skewed toward females. Sex ratios differ significantly by season and location. Seasonally, the sex ratio is 0.29 in April, 0.76 in June, and 0.39 in August. The sex ratio for reef-flank samples is 0.31 , compared to 0.54 for reef-flat samples. Overall, $20 \%$ of the adult females were carrying eggs.

\section{Teleophrys cristulipes Stimpson}

This spider crab (CL 5.5 to $6.9 \mathrm{~mm}$ ) is usually collected in Pocillopora, but is also common in the rocky intertidal (Garth, 1958). Garth reports that specimens not found on Pocillopora are large, smooth-legged, and with a lumpy carapace. Individuals from coral heads are smaller, with cristate legs, and with spinous lateral margins. Teleophrys cristulipes is restricted to the Eastern Pacific (Rathbun, 1925) and ranges from the Gulf of California to Equador (Garth, 1958). Within this range, clinal variation in morphology is evident: in northern individuals the anterior branchial region of the carapace is enlarged, the rostrum is deeply cleft, and the propodus lacks ornamentation. In southern individuals the anterior branchial region is reduced, the rostrum has 2 shallow lobes, and 1 lateral tubercle or spine may be present on the propodus (Garth, 1939). $T$. cristulipes is very abundant in the Galapagos, and Galapagos specimens are larger than other Eastern Pacific specimens (Garth, 1939). In the Perlas Islands, Panama, abundance of $T$. cristulipes is negatively cor- 
related with coral head size (Abele and Patton, 1976). Feeding habits are undescribed. In rocky intertidal pools, individuals have been observed (by SLG) ingesting the green alga Caulerpa.

Teleophrys cristulipes was present on $82 \%$ of the coral heads. Coral-head size accounts for $21 \%$ of the variation in abundance (Table 1). Seasonal differences in density are highly significant (ANCOVA $F_{3,114}=$ 29.19, $\mathrm{p}<0.01)$. Adjusted mean densities are similar in January $\left(\overline{\mathrm{x}}=3.00\right.$ indiv. head $\left.{ }^{-1}\right)$, April $(\overline{\mathrm{x}}=3.13)$, and June $(\overline{\mathrm{x}}=3.89)$, but are depressed in August $(\overline{\mathrm{x}}=$ $0.33)$. This difference occurs because 7 out of the 10 August samples had no individuals. If empty heads are excluded, seasonal differences are not significant $\left(\right.$ ANCOVA $\left.F_{3,93}=1.23, \mathrm{p}>0.05\right)$.

In a presence-absence analysis, the presence by season interaction is highly significant $\left(\chi^{2}=19.77\right.$. $\mathrm{p}=0.0002$ ). In August, Teleophrys cristulipes is present on only $20 \%$ of the heads, compared to $57 \%$ in January, $83 \%$ in April, and $100 \%$ in June. Coral head size also has a significant effect on occurrence. Of the small heads $27 \%$ were empty, compared to only $7 \%$ of the larger heads.

All of the population parameters appear constant by season and reef location. Of the individuals collected $21 \%$ were adults. The adult sex ratio is 1.25 , skewed toward males. Of the adult females $50 \%$ were carrying eggs.

\section{DISCUSSION}

Except for Trapezia formosa and Teleophrys cristulipes, regressions of egg number on carapace length are significant for all species. This result is not suprising considering the morphological changes associated with egg production. Enlargement of the carapace in all 3 directions ( $=$ volumetric increase) allows an individual to increase egg production; egg number is related to female body size with a very high exponent. We are puzzled by the lack of significance for $T$. formosa; this result is atypical for morphometric studies of decapods. Perhaps it is related to the small size range of gravid females in our samples.

From the male's point of view, reproductive output may be increased by mating with a larger female or with several females. However, extreme differences in the body size of paired males and females are not expected because of behavioral interactions. Accordingly, paired male and female Trapezia are of similar body size, although females are slightly larger (Preston, 1973; Castro, 1978).

For the sponge crab Cryptodromia, McClay (1982) suggests that small males may be less susceptible to predation while searching for mates. However, his arguments apply to cryptic species, such as sponge or spider crabs. Trapezia are brightly colored and conspicuous to predators; any individual that leaves the coral head by day is susceptible to predation, regardless of its size. Castro (1978) found that migration of T. ferruginea is suppressed in the presence of fish predators. But more males tended to migrate than females in his experiments (females $40 \%$, males $87.6 \%, \mathrm{p}=.035$; data from Table 4 in Castro, 1978). Interestingly, the sex ratio for $T$. ferruginea in this study is significantly skewed toward females. If male $T$. ferruginea tend to migrate more often, they may suffer increased mortality, skewing the sex ratio.

The number of putative heterosexual pairs in this study is highly variable, from 1 to 4 pairs per coral head for both Trapezia ferruginea and $T$. corallina and single pairs for $T$. formosa. While coral head size is correlated with the number of pairs, it accounts for less than $30 \%$ of the variation in numbers (Table 1). The occurrence of multiple pairs is in contrast to results from the adjacent Bay of Panama (Abele and Patton, 1976; Castro, 1978), Australia (Patton, 1974), Hawaii (Preston, 1973), and the Maldives (Garth, 1964), where 1 , or at most 2, pairs of Trapezia are found per coral head.

If, as Castro's (1978) data suggest, individuals migrate often, then perhaps the occurrence of a male and female together does not represent a monogamous pair. It is difficult to conceive of precise pairing in light of the heterogeneous assemblages of male and females found on coral heads at Uva Island.

Patterns of body size and population structure suggest that recruitment of Trapezia onto coral heads occurs in April or June; juvenile crabs grow to sexual maturity by January. Like other tropical brachyurans, female Trapezia carry eggs throughout the year. Yet, the distribution of postlarvae on coral heads is strikingly discontinuous (Fig. $2 \mathrm{C}$ ). We are puzzled by the complete absence of postlarvae in January and August. An extreme low tide killed many Pocillopora heads on the reef flat just prior to the January sampling (Glynn, 1976); postlarvae may also have been killed at this time. However, postlarvae were also missing from the deeper reef-flank corals, as well as from the August collections. Although adult Trapezia associate exclusively with live coral heads, nothing is known of the ecology of the dispersive larval and postlarval stages. Perhaps postlarvae recruit seasonally from other habitats; samples from nearby coral rubble might be revealing.

The abundance of Trapezia ferruginea and T. corallina is significantly correlated with coral-head size. Whereas seasonal effects on abundance are negligible, reef location appears quite important. The abundance of $T$. ferruginea and the frequency of occurrence of $T$. formosa are both higher on the reef flat. Total abun- 
Table 2. Significant correlations among population and environmental variables. + indicates a significant correlation between 2 variables $(\mathrm{p}<.05)$. 'Conditional density' statistics were calculated only for samples in which individuals were present; all other statistics were calculated for all samples

\begin{tabular}{|c|c|c|c|c|}
\hline Species & Populations measure & Area & Season & Location \\
\hline Trapezia ferruginea & $\begin{array}{l}\text { Density } \\
\text { Conditional density } \\
\text { Presence/absence } \\
\text { Adult/juvenile } \\
\text { Adult male/adult female } \\
\text { Male/female } \\
\text { Gravid/non-gravid female }\end{array}$ & $\begin{array}{l}+ \\
+\end{array}$ & + & $\begin{array}{l}+ \\
+\end{array}$ \\
\hline Trapezia corallina & $\begin{array}{l}\text { Density } \\
\text { Conditional density } \\
\text { Gravid/non-gravid female }\end{array}$ & $\begin{array}{l}+ \\
+\end{array}$ & + & + \\
\hline Trapezia formosa & $\begin{array}{l}\text { Density } \\
\text { Presence/absence }\end{array}$ & & & $\begin{array}{l}+ \\
+\end{array}$ \\
\hline Alpheus lottini & $\begin{array}{l}\text { Density } \\
\text { Conditional density }\end{array}$ & $\begin{array}{l}+ \\
+\end{array}$ & & + \\
\hline Fennera chacei & $\begin{array}{l}\text { Density } \\
\text { Conditional density } \\
\text { Adult/juvenile }\end{array}$ & $\begin{array}{l}+ \\
+\end{array}$ & $\begin{array}{l}+ \\
+\end{array}$ & \\
\hline Harpiliopsis depressa & $\begin{array}{l}\text { Density } \\
\text { Conditional density } \\
\text { Male/female } \\
\text { Gravid/non-gravid female }\end{array}$ & $\begin{array}{l}+ \\
+\end{array}$ & $\begin{array}{l}+ \\
+ \\
+\end{array}$ & $\begin{array}{l}+ \\
+\end{array}$ \\
\hline Teleophrys cristulipes & $\begin{array}{l}\text { Density } \\
\text { Conditional density } \\
\text { Presence/absence }\end{array}$ & $\begin{array}{l}+ \\
+ \\
+\end{array}$ & $\begin{array}{l}+ \\
+\end{array}$ & \\
\hline
\end{tabular}

dances and species richness of all decapods are also higher on the reef flat (Edwards and Emberton, 1980; Gotelli and Abele, 1983). Pocillopora cover is more continuous and predatory fish are less common on the shallow reef flat (Glynn et al., 1972). Bath factors could contribute to the greater abundance of decapods in this location.

In spite of their apparent morphological similarity, coexisting species of Trapezia are quite distinct in their population structure. This statement applies not only to Trapezia but also to other associates of Pocillopora. Table 2 summarizes the significant patterns for each species.

One notable result is the relative importance of coral head size to population structure. At the 'community' level, the area effect is extremely important. It dominates patterns of species richness and abundance (Abele, 1976b; Abele and Patton, 1976) and even affects measures of interspecific association (Gotelli and Abele, 1983). At the 'population' level, its effect is much weaker. Area correlates significantly with abundance for 6 of the 7 common species, but the correlation coefficients are all rather small (Table 1). Coral head size does influence the frequency of occurrence of Teleophrys cristulipes, but is not significantly associated with any other population measures. Frequency of occurrence has an important effect on the measurement of abundance. In 6 cases (Trapezia ferruginea, Trapezia formosa, Alpheus lottini, Fennera chacei, Harpiliopsis depressa, Teleophrys cristulipes) we detected, with an analysis of covariance, seasonal or locational variation in the abundance of a species. But only for $T$. ferruginea did the average number of individuals per coral head actually differ. In the other cases, frequency of occurrence also varied by location or season. When the species actually occurred, abundances were similar; in other words, the conditional density of the species did not change.

Both season and reef location emerge as important factors influencing population structure. As we noted above, Pocillopora cover and predation intensity vary between reef flat and reef flank. Seasonal differences in water quality are also evident at Uva Island. Although seasonal upwelling does not occur in the Gulf of Chiriqui, this region experiences distinct wet and dry seasons (Dana, 1975; Glynn, 1977). During the wet season (May through Nov), sea surface temperatures and salinity are lower. In addition, freshwater runoff increases turbidity and reduces light penetration. Pesticide input may be high from this runoff 
(Glynn, 1983b). Dana (1975) estimates that light penetration at $10 \mathrm{~m}$ may be 3 times greater during the dry season.

While the crustaceans depend on Pocillopora heads for a habitat and coral mucus for a food source (Patton. 1974), their presence is also essential for the health of the host coral. If symbionts are removed, Pocillopora mucus production drops, the polypal layer disintegrates, and massive tissue exfoliation occurs (Glynn, 1983a). Thus, interactions with the coral host are likely to influence crustacean population structure.

The patterns described in this study may no longer hold. Early in 1983 (Feb-Mar), extensive bleaching and massive death of Pocillopora and other corals occurred in the Gulf of Chiriqui. Bleached coral heads contained 9 or 10 crustacean symbionts, compared to 22 on healthy corals. Dead corals contained on average less than a single individual per colony (Glynn, 1983b). Although the cause of this bleaching and death is unknown, abnormally high water temperatures associated with a strong El Niño current (Philander, 1983; Glynn, 1984) have been implicated. Coral death and its effects on crustacean populations in the Gulf of Chiriqui are currently being monitored (Glynn and Gilchrist, in prep.).

Acknowledgements. We thank Peter Glynn for access to the Uva Island samples. Don Strong, Joe Travis, and three anonymous reviewers made useful comments on the manuscript.

\section{LITERATURE CITED}

Abele, L. G. (1976a). Comparative species richness in fluctuating and constant environments: coral-associated decapod crustaceans. Science, N. Y. 192: 461-463

Abele, L. G. (1976b). Comparative species composition and relative abundance of decapod crustaceans in marine habitats of Panama. Mar. Biol. 38: 263-278

Abele, L. G. (1979). The community structure of coral-associated decapod crustaceans in variable environments. In: Livingston, R. 3. (ed.) Ecological processes in coastal and marine systems. Plenum Press, New York, p. 265-287

Abele, L. G. (1984). Biogeography, colonization and experimental structure of coral-associated crustaceans. In Strong, D. R., Simberloff, D., Abele, L. G., Thistle, A. B. (ed.) Ecological communities: conceptual issues and the evidence. Princeton University Press, Princeton, N.J., p. $123-137$

Abele, L. G., Patton, W. K. (1976). The size of coral heads and the community biology of associated decapod crustaceans. J. Biogeogr, 3: 35-47

Austin, A. D., Austin, S. A., Sale, P. F. (1980). Community structure of the fauna associated with the coral Pocillopora damicornis (L.) on the Great Barrier Reef. Aust. J. mar. Freshwat. Res. 31: 163-174

Barry, C. K. (1965). Ecological study of the decapod crustaceans commensal with the branching coral Pocillopora meandrina var. nobilis Verrill. M. S. thesis, University of Hawaii, Honolulu, Hawaii
Black, R., Prince, J. (1983). Fauna associated with the coral Pocillopora damicornis at the southern limit of its distribution in Western Australia. J. Biogeogr. 10: 135-152

Bruce, A. J. (1970). On the identity of Periclimenes pusillus Rathbun, 1906 (Decapoda, Pontoniinae). Crustaceana 19: $306-310$

Bruce, A. J. (1976). Coral reef caridea and 'commensalism' Micronesia 12: 83-98

Bruce, A. J. (1981). Pontoniine shrimps of Heron Island. Atoll Res. Bull. 245: 1-33

Castro, P. (1976). Brachyuran crabs symbiotic with scleractinian corals; a review of their biology. Micronesia 12 : 99-110

Castro, P. (1978). Movements between coral colonies in Trapezia ferruginia (Crustacea: Brachyura), an obligate symbiont of scleractinian corals. Mar. Biol. 46: 237-245

Castro, P. (1982). Notes on symbiotic decapod crustaceans from Gorgona Islands, Columbia, with a preliminary revision of the eastern Pacific species of Trapezia (Brachyura, Xanthidael, symbionts of the scleractinian corals. An. Ist. Inv. Mar. Punta Betin 12: 9-17

Coles, S. L. (1980). Species diversity of decapods associated with living and dead reef coral Pocillopora meandrina. Mar. Ecol. Prog. Ser. 2: 281-291

Coutiere, H. (1899). Les 'Alpheidae', morphologie externe et interne, formes larvaires, bionomie. Ann. Sci. Nat. Zool. 8 Ser. 9: $1-560$

Crane, J. (1937). The Templeton Crocker Expedition. III. Brachygnathous crabs from the Gulf of California and the west coast of Lower California. Zoologica 22: 47-78

Dana, T. F. (1975). Development of contemporary Eastern Pacific coral reefs. Mar. Biol. 33: 355-374

Edwards, A., Emberton, H. (1980). Crustacea associated with the scleractinian coral, Stylophora pistillata (Esper), in the Sudanese Red Sea. J. exp. mar. Biol. Ecol. 42: 225-240

Finney, W. C., Abele, L. G. (1982). Allometric variation and sexual maturity in the obligate coral commensal Trapezia ferruginea Latreille (Decapoda, Xanthidae). Crustaceana 41: $113-130$

Garth, J. S. (1939). New brachyuran crabs from the Galapagos Islands. Allan Hancock Foundation Pacific Expeditions, Vol. 5, No. 2, 1-638

Garth, J. S. (1958). Brachyura of the Pacific coast of America. Oxyrhyncha. Allan Hancock Foundation Pacific Expeditions, Vol. 21, Pt. 1, 1-499

Garth, J. S. (1964). The Crustacea Decapods (Brachyura and Anomura) of Eniwetok Atoll, Marshall Islands, with special reference to the obligate commensals of branching corals. Micronesia 1: 137-144

Glynn, P. W. (1976). Some physical and biological determinants of coral community structure in the eastern Pacific. Ecol. Monogr. 46: 431-456

Glynn, P. W. (1977). Coral growth in upwelling and nonupwelling areas off the Pacific coast of Panama. J. mar. Res. 35: 567-585

Glynn, P. W. (1980). Defense by symbiotic crustacea of host corals elicited by chemical cues from predators. Oecologia 47: $287-290$

Glynn, P. W. (1983a). Increased survivorship in corals harboring crustacean symbionts. Mar. Biol. Lett. 4: 105-111

Glynn, P. W. (1983b). Extensive 'bleaching' and death of reef corals on the Pacific coast of Panama. Environ. Cons. 10: $149-154$

Glynn, P. W. (1984). Widespread coral mortality and the 1982-83 El Niño warming event. Environ. Conserv. 11: 28-41

Glynn, P., Stewart, R. H., McCosker, J. E. (1972). Pacific coral 
reefs of Panama: structure, distribution, and predators. Geol. Rdsch. 61: 483-519

Gotelli, N. J., Abele, L. G. (1983). Community patterns of coral-associated decapods. Mar. Ecol. Prog. Ser. 13: 131-139

Holthuis, L. B. (1951). A general revision of the Palaemonidae (Crustacea Decapoda Natantia) of the Americas. I. The subfamilies Euryrhynchinae and Pontoniinae. Allan Hancock Foundation Publications of University of Southern California, U.S.C. Press, Los Angeles, California

Huitema, B. E. (1980). The analysis of covariance and alternatives. John Wiley and Sons, Inc., New York

Knudsen, J. W. (1967). Trapezia and Tetralia (Decapoda, Brachyura, Xanthidae) as obligate ectoparasites of pocilloporid and acroporid corals. Pacif. Sci. 21: 51-57

McClay, C. L. (1982). Population biology of the sponge crab Cryptodromia hilgendorfi (Dromiacea) in Moreton Bay, Queensland, Australia. Mar. Biol. 70: 317-326
Patton, W. K. (1966). Decapod crustacea commensal with Queensland branching corals. Crustaceana 10: 271-295

Patton, W. K. (1974). Community structure among the animals inhabiting the coral Pocillopora damicomis at Heron Island, Australia. In: Vernberg, W. B. (ed.) Symbiosis in the sea. University of South Carolina Press, Columbia, p. $219-243$

Philander, S. G. H. (1983). El Niño southern oscillation phenomena. Nature, Lond. 302: 295-301

Preston, E. M. (1973). A computer simulation of competition among five sympatric congeneric species of xanthid crabs. Ecology 54: 469-483

Rathbun, M. J. (1925). The spider crabs of America. Smithson. Inst. Nat. Mus. Bull. 129

Weber, J. N., Woodhead, P. M. J. (1970). Ecological studies of the coral predator Acanthaster planci in the south Pacific. Mar. Biol. 6: 12-17

This paper was submitted to the editor; it was accepted on September 15, 1984 